\title{
Amendment Change Summary Version Document
}

National Cancer Institute

\section{Source}

National Cancer Institute. Amendment Change Summary Version Document. NCI

Thesaurus. Code C93379.

A document, memo or brief that enumerates the differences between two versions of a study protocol document. 